\title{
The Status of the Non-Muslim Communities in the Ottoman Empire: A Non-Orientalised Decolonial Approach
}

\author{
El status de las comunidades no musulmanas en \\ el Imperio Otomano: un enfoque descolonial no \\ orientalizadoTítulo em espanhol
}

\section{O status das comunidades não muçulmanas no Império Otomano: uma abordagem descolonial não orientalizada}

1. Dr Naif Bezwan, Senior Researcher at the Ludwig Boltzmann Institute of Fundamental and Human Rights, Department of Constitutional and Administrative Law, Faculty of Law at University of Vienna, and Honorary Senior Research Associate at the Department of Political Science, University College London (UCL). Dr Bezwan has worked, conducted research, and taught at diverse universities in Germany, Turkey, Austria and the UK.

\author{
Naif Bezwan'1
}

DOI: 10.5752/P.2317-773X.2020v8.n4.p10

Received in: September 21, 2020

Accepted in: September 23, 2020

\begin{abstract}
With a focus on the key developments and critical junctures that shaped and reshaped the relationship between the Ottomans and its non-Muslim subject communities, this paper seeks to understand the dynamics and the rationale behind the Ottoman policies and practices vis-a-vis non-Muslim communities. It will do so by offering a periodisation of Ottoman rule along four major pathways, each of which also provides the title of the respective section. The first period is referred to as structural exclusion by toleration over centuries, from the conquest of the respective territories to their incorporation into the imperial domain. The second phase is entitled integration via politics of recognition which basically covers the Tanzimat era (1838-1876). The third period is put under the heading of coercive domination and control, roughly corresponding to the Hamidian Period (1876-1908). And finally, the last period is concerned with the Young Turks regime (1908-1918), discussing its politics and policies towards non-Muslims communities framed under the title of nation-building by nation-destruction.

These section headings act both as hypothesis and structuring elements of the pe-riodisation presented. As such they shall help identify the dominant paradigm of each period pertinent to the status and situation of the communities under consideration, while connecting them in a plausible manner. This paper is motivated by a non-Orientalised decolonial approach to the study of the Ottoman empire as well as the nation-states established in the post-Ottoman political geographies.
\end{abstract}

Keywords: Non-Muslim communities. Ottoman reforms. Millet System. Decolonial approach. 


\section{RESUMEN}

Con un enfoque en los desarrollos clave y las coyunturas críticas que dieron forma y remodelaron la relación entre los otomanos y sus comunidades de sujetos no musulmanes, este documento busca comprender la dinámica y el fundamento detrás de las políticas y prácticas otomanas frente a los no musulmanes. Comunidades musulmanas. Lo hará ofreciendo una periodización del dominio otomano a lo largo de cuatro vías principales, cada una de las cuales también proporciona el título de la sección respectiva. El primer período se denomina exclusión estructural por tolerancia durante siglos, desde la conquista de los respectivos territorios hasta su incorporación al dominio imperial. La segunda fase se titula Integración a través de políticas de reconocimiento que cubre básicamente la era Tanzimat (1838-1876). El tercer período se clasifica bajo el título de dominación y control coercitivo, que corresponde aproximadamente al período Hamidiano (1876-1908). Y finalmente, el último período se refiere al régimen de los Jóvenes Turcos (1908-1918), discutiendo su política y políticas hacia las comunidades no musulmanas enmarcadas bajo el título de construcción nacional por destrucción nacional.

Los títulos de los capítulos actúan como hipótesis y como elementos estructurantes de la periodización presentada. Como tales, ayudarán a identificar el paradigma dominante de cada período pertinente al estado y situación de las comunidades en consideración, al mismo tiempo que las conecta de manera plausible. Este artículo está motivado por un enfoque descolonial no orientalizado del estudio del imperio otomano, así como de los estados-nación establecidos en las geografías políticas post-otomanas.

Palabras clave: comunidades no musulmanas. Reformas otomanas. Sistema Millet. Abordaje decolonial.

\section{Resumo}

Com foco nos principais desenvolvimentos e conjunturas críticas que moldaram e remodelaram a relação entre os otomanos e suas comunidades não-muçulmanas, este artigo busca compreender a dinâmica e a lógica por trás das políticas e práticas otomanas vis-à-vis Comunidades muçulmanas. Ele fará isso oferecendo uma periodização do domínio otomano ao longo de quatro caminhos principais, cada um dos quais fornece também o título da respectiva seção. O primeiro período é denominado de exclusão estrutural por tolerância ao longo dos séculos, desde a conquista dos respectivos territórios até sua incorporação ao domínio imperial. A segunda fase é intitulada integração via política de reconhecimento que cobre basicamente a era Tanzimat (1838-1876). O terceiro período é colocado sob o título de dominação e controle coercitivos, correspondendo aproximadamente ao Período Hamidiano (1876-1908). E, finalmente, o último período trata do regime dos Jovens Turcos (1908-1918), discutindo suas políticas e políticas em relação às comunidades não muçulmanas enquadradas sob o título de construção da nação pela destruição da nação. Os títulos dos capítulos funcionam como hipótese e elementos estruturantes da periodização apresentada. Como tal, devem ajudar a identificar o paradigma dominante de cada período pertinente ao status e à situação das comunidades em questão, ao mesmo tempo que os conecta de maneira plausível. Este artigo é motivado por uma abordagem descolonial não orientalizada do estudo do império otomano, bem como dos estados-nação estabelecidos nas geografias políticas pós-otomanas.

Palavras-chave: comunidades não muçulmanas. Reformas otomanas. Sistema Millet. Abordagem decolonial. 
1. Hans-Lukas Kieser has rightly pointed out that the millet communities were called "minorities" in Western terminology, as well as in the Lausanne Treaty (July 24, 1923) which laid down the post-Ottoman order in the Middle East, and led to the proclamation of the Turkish republic on 29. October 1923.

Since there was no clear majority even in the imperial core region in ethno-religious terms, the term "population group", Kieser concludes, is more accurate, referring that Ottomans themselves used the word unsur ("element" (KIESER, 2019, p. 2)

2. For example, the Arabic-speaking Orthodox Christians called themselves simply the Rum, a collective noun which could mean alternatively "Byzantines",

"Anatolians", "Greeks or "Orthodox Christians" in Ottoman Turkish, while in Syrian Arabic, Rum could also mean ' "Ottomans" in addition to the other possible meanings (MASTERS, 2001, p. 50).
Introduction

The Ottoman Empire existed for over six centuries and was both a land-based and maritime empire, at times ruling indirectly through indigenous elites and at times sending out settlers to colonise new areas (MIKHAIL; PHILLIOU, 2012). It ruled over an ethnically and religiously diverse population in the Balkans, Asia Minor, Iraq, Syria, the Arab peninsula, and Northern Africa. It is considered as the most religiously diverse empire in Europe and Asia and was home to large groups of Christians and a significant number of Jews (KIESER, 2019, p. 4).

By their very nature empires are large macro-historical entities. An empire, as Tilly observes, is a large composite polity linked to a central power by indirect rule whereby,

\footnotetext{
" $[t]$ he central power exercises some military and fiscal control in each major segment of its imperial domain, but tolerates the two major elements of indirect rule: (1) retention or establishment of particular, distinct compacts for the government of each segment; and (2) exercise of power through intermediaries who enjoy considerable autonomy within their own domains in return for the delivery of compliance, tribute, and military collaboration with the center" (TILLY, 1997, p. 3).
}

Despite the difficulties involved, historically grounded huge comparisons of big structures and large processes can help us "establish what must be explained, attach the possible explanations to their context in time and space, and sometimes actually improve our understanding of those structures and processes" (TILLY, 1989, p. 145).

Before examining each period in some detail, I shall make some methodological, terminological, and contextual remarks concerning how the subject matter should be framed. To begin with, this paper will largely avoid using the term "minority" as it is a modern category, which was adopted by the Ottoman Empire during the Tanzimat period. More importantly, talking about minorities in imperial settings like the Ottoman is somewhat problematic because, depending on what criteria is used, the designation of minority and majority could immediately change'. For example, in Rumeli, there was a clear Christian majority with substantial portions of Muslim minorities, whereas in Anatolia there was a clear Muslim majority with substantial portions of Christians, Jews, and other groups. In the same vein, if one takes nationality as the main criterion for establishing minorities and majorities, things may even get more complicated, as many national-cultural groups were dispersed across imperial domains, while retaining some core areas where they make up a majority.

The same applies to the Turks who were an absolute minority within the empire (Levene 2013, p.24). The centre and capital city of the Ottoman Empire, Istanbul, is a case in point. As late as the Balkan wars of 1911-1913, roughly equal portions of Muslim and Christian subjects lived in Istanbul, but during the twentieth century Christian populations also diminished, as Sharkey notes, "historic Christian communities persisted but dwindled as a proportion of the population" (SHARKEY, 2017, p. 2). So, the Ottoman empire was essentially a composite of two core political geographies: Anatolia (or Asia Minor) and Rumeli (or the land of the Romans). ${ }^{2}$ The former was regarded by Ottoman ruling elites as 
constituting the territorial core of the empire where its initial victories and conquests were achieved, while Rumeli was perceived as possessing the empire's most significant cities and wealthiest stretches of farmland (GINGERAS, 2016, p.56).

This leads me to my second point, relating to the term "non-Muslim" which comprises such a large category of diverse peoples and confessional groups that are anything but monolithic and homogenous. The term "non-Muslim" refers to multiple communities composed of Christians, Jews and others that lived across the imperial domains extending over different geographies marked by significant cultural, societal and confessional and class differences (SHARKEY, 2017, p. $16 \mathrm{ff}$.). That is why the turn of phrase non-Muslim should not in any way be understood as assigning a primordial, monolithic and unchanging mass of peoples, or as oppositional to Muslim communities or vice versa. It is therefore neither about a "clash of civilizations" nor grounded in any assumption that posits a binary opposition between cultures and civilizations. Cultural distinctions, to paraphrase Said, cannot be seen as "frozen reified set of opposed essences" to be evoked for the purposes of adversarial knowledge production drawn from supposedly irreconcilable things (SAID, 2004, p. 352).

This brings me to my third point: Each period here under consideration is shaped by a set of historical developments and socio-economic processes that affected the nature of the relations between the Ottomans, its rivals and as well its subject communities. While keeping in mind that there were always considerable amounts of overlap between the four main eras presented here, the periodization is constructed as a heuristic framework "in which significant patterns of fact can be identified, causal relationships investigated and phenomena classified” (LEVENE, 2005, p. 66). As such, it is intended to provide points of reference against which commonalities and differences, as well as continuities and variations, in the conduct of the Ottoman public policies towards non-Muslim minorities/confessional groups can be better assessed.

Put differently, the periodisation offered here is not taken to mean that the outcomes were inevitable or the shift from one period to the other was predetermined at all. Nor is it meant to deny the significant areas of overlap between the periods, or the power and agency of the communities involved to shape their lives under ever-changing and challenging circumstances. Even under conditions of structural exclusion there were many non-Muslim communities across the Ottoman empire, especially those located predominantly in thriving ports, such as Izmir and Salonica where

\footnotetext{
"non-Muslim entrepreneurs enjoyed two major advantages: they possessed the necessary human capital and they were perfectly embedded in local networks. While the former was a necessary skill to bypass local Muslim groups, the latter gave them a distinct advantage over Europeans” (EMRENCE, 2008, p.300).
}

In his masterfully examined study on Christians and Jews in the Ottoman Arab World, Bruce Masters shows the same trend in the Fertile Crescent from Aleppo to Beirut and almost as far as Damascus:

"Christian merchants were able to supplant eventually their Jewish rivals for second place in the trading hierarchy. By way of contrast, Jewish merchants predominated in the all-important Indian trade with Iraq, although Christian and Muslim merchants were also active” (MASTERS, 2001, p. 143). 
This trend is most visible during the Tanzimat period. Despite the fact that during the Tanzimat period the overwhelming majority of Christians and Jews living in the Ottoman Arab were not merchants - indeed in the cities of the region, most remained craftsmen or low-skilled workers - a Christian commercial middle class emerged in every port on the eastern Mediterranean seaboard and in Mosul and Damascus as well, while a parallel Jewish bourgeoisie was present in Baghdad and Basra (MASTERS, 2001, p. 144.). It follows that non-Muslims communities under the Ottoman rule were not simply passive recipients of a changing world order imposed on them but rather "they took an active lead in devising strategies to cope with change and benefit from it, thereby determining their own futures" (MASTERS, 2001, p 15.). As stated by Makdisi (2002) the "Christians as a whole were routinely described as infidels, yet they were tolerated; others such as Yezidi Kurds and Druzes were often described as heretics, but their heresy was often overlooked" (MAKDISI, 2002, p. 774.).

The fourth point is that not all communities were equally affected by Ottoman policies. For example, as Braude points out in the case of the Iberian Jews (i.e. Jews who had been expelled from Spain and Portugal in 1492) that of all the Ahimmi communities, they alone were Ottoman subjects by choice, not by conquest, a characteristic that "distinguished them from the Christian communities and proved a source of suspicion in the eyes of their fellow subjects and of acceptance in the eyes of their masters" (BRAUDE, 2014, p. 37). In a similar vein, the Greeks' relationship to the Ottomans is considered to have been multi-layered, as different elements of the population had different privileges and responsibilities with "varying degrees of autonomy verging on effective independence" (BRAUDE, 2014, p. 25).

Finally, while trying to understand the factors related to the subject under review, it is important to emphasize the significance of the geographical/regional dimensions. More specifically, the geostrategic location of the settlement areas in combination with the level of effective rule by the Ottomans are among the factors that played a significant role in the degree of autonomy from, or exposure to, Ottoman governance. For example, owing to the lack of control and access to their settlement, the Maronites - one of the most important and influential Christian communities in the Fertile Crescent - were in a position to challenge the Ottoman policies. This meant that the leaders and dignitaries of this community "could flaunt in their mountain redoubts their disregard for many of the legal restrictions imposed on non-Muslims elsewhere, building new churches and monasteries, openly carrying arms, and riding horses. What was unthinkable in the rest of the sultan's domains could occur almost seamlessly in Mount Lebanon, with the open conversion to Christianity by individuals from two politically dominant clans of the Mountain, the Sunni Shihab and the Druze Abu-Lammac, in the early nineteenth century without apparent repercussion" (MASTERS, 2001, p. 43-44). This degree of freedom on the part of the Maronite community resulted from "the existence of their patriarch and church hierarchy outside the zone of direct Ottoman control" that gave the Maronites everywhere an opportunity for freedom of political action not shared by most other Christians in the Ottoman period (MASTERS, 2001, p. 44). 
Taken together, the "Ottoman imperial paradigm [was] based on a hierarchical system of subordination along religious, class, and ethnic lines" (MAKDISI, 2002, p. 768). The fundamentally subdued and precarious status of communities was defined by the Ottoman policies of accommodation and suppression (MAKDISI, 2002, p. 777) on the one hand, and change and adaptation on the parts of the communities involved on the other (MASTERS, 2001, p. 13).

Having clarified the terminological and methodological understanding of this paper, in what follows, I shall discuss the dynamics and processes that shaped the situation of all communities under Ottoman rule - Muslim and non-Muslim alike.

An Overview of historical Context

It should be clear from the above that the bulk of the phenomena, institutions and ideas dealt with in this paper are nothing but modern occurrences and experiences. Whether it be the industrial revolution or the rise of capitalism as a global system or the changing rules of colonial expansionism or the logic of direct rule, the nation-state formation or the concepts of modernization and national emancipation - all of these were the features of modernity which emerged over the course of the 18th century and became ever more relevant to the Ottoman empire during the course of the nineteenth century up until its dissolution in the wake of the First World War.

The story, then, is not simply one about a medieval empire caught in its death throes versus the civilised European Great Powers. Nevertheless, the Ottoman predicament stands and falls with its diminishing power to expand further. Following a couple of momentous defeats and interventions during the course of the eighteenth century by the rival powers, the Ottoman Empire itself, once a fearsome "imperial aggressor", became subject to a more powerful imperialism (SHARKEY, 2017, p. 95). ${ }^{3}$ Moreover, from the late eighteenth century onward, it faced an increasingly disobedient Christian population supported by Russia along with the other European powers that "increasingly pressed claims for the protection of entire communities. But unlike all the other powers, Russia could claim the demographically largest and strategically most significant of all, the Rum" (BRAUDE, 2014, p. 43). This state of affairs was accompanied and reinforced by the combined effects of "European thought, the Enlightenment, liberalism, and nationalism as well as the powerful engines of Europe's capital and industry" (ibid.). All of this undermined the basic assumptions of the Ottoman order, chipped away at its economy and fundamentally affected its heterogeneous social fabric.

At the turn of the nineteenth century, three major factors can be identified as causally relevant to the historical context under consideration: the Ottoman drive towards effective rule across imperial domains, European expansionism in the context of an ever-shifting balance of power in economical, technological and ideological terms at the expense of the Ottoman Empire, and the collective aspirations and actions for emancipation on the part of diverse subject communities under Ottoman
3. Important among these events were the Treaty of Karlowitz of 1699, which followed an Ottoman defeat by the Habsburg Empire and the loss of territories, the Treaty of Küçük Kaynarca of 1774, which provided the Russian with tremendous influence over the Orthodox Christian population in the Ottoman Empire, and finally, Napoleon's invasion of Egypt in 1798, which inaugurated a French occupation of the country that lasted for three years (SHARKEY, 2017, p. 95 ff.). 
rule. However, the ways in which this trivalent interrelationship evolved is anything but straightforward, as it involved a complex and conflictual matrix of power relations with many convergences and divergences of interests and changing patterns of alliance and hostility.

The nature of these power relations with their multiple conflicts and convergences can be captured in what historian Leon Carl Brown called "the Eastern Question system" i.e. the long process of dismembering of the Ottoman empire without disturbing the European balance of power from the late eighteenth century until just after the First World War (BROWN, 1984, p. 5). Out of this process came an "elaborate, multiplayer diplomatic game involving many different European states as well many different Middle Eastern states" (BROWN, 1984, p. 5). Continuing for generations, Brown maintains, "the Eastern Question itself created a particular attitude toward politics and diplomacy among the players involved which still exists" (BROWN, 1984, p. 7).

While contingent upon conflicting as well as intersecting interests around the "Eastern question", this peculiar balance of power with its ever-shifting alliances ultimately determined the character of relations and interactions among the unequal parties throughout the 19th century up to the dissolution of the Ottoman Empire in the wake of the First World War. The late Ottoman period can be seen as an unfolding of the triangular relationship between the politics of the European Great Powers, the national aspirations of various nationalist movements, and the Ottoman politics of centralisation and nation-building. The imperial designs of the European Great Powers on the Ottoman Empire, however, provided the Ottomans both with political opportunities as well as a threat to its domination. Equally, the struggles of the emergent national movements for autonomy and/or independence provided both justification for intervention by the one or other European power on behalf of the respective community, and justification for the Ottoman state to more rigorously impose direct rule, nation-building or reforms, respectively.

Historian Hanioğlu seems to take issue with the fact that nationalist movements, the aspirations of local rulers, and international encroachments exerted an ever-stronger pull in the opposite direction, as "the imperial center took advantage of the possibilities afforded by modern technology to launch an ambitious attempt to centralize and modernize the mechanisms of control over the loosely held periphery" (HANIOĞLU, 2008, p.4). Makdisi (2002), in turn refers to a fundamental shift from the earlier imperial paradigm of accommodation to "an imperial view suffused with nationalist modernization rooted in a discourse of progress" (2002, p. 769). Accordingly, Ottoman modernization

\footnotetext{
"supplanted an established discourse of religious subordination in which an advanced imperial center reformed and disciplined backward peripheries of a multi-ethnic and multi-religious empire which led to the birth of Ottoman Orientalism" (ibid.).
}

Referring to the European power politics throughout the nineteenth century, Michael Mann suggests that the Great Power diplomacy was consciously geared to the very opposite of hegemonic stability theory. All agreements had accordingly two objectives: 
"to prevent any single Power becoming hegemonic in any region of Europe and to preserve order, emphasizing that "order" was meant to different powers differently. For the reactionary monarchs, it meant regulating both international and domestic strife and repressing reform. For the liberal Powers, it meant avoiding revolution by allowing bourgeois and "national" self-determination" (MANN 2012A, p. 281ff.).

Diplomats had to preserve peace and order, "including reactionary class and market order, by avoiding hegemony, while coping "with the rise of the nation at odds with the existence of many existing states" (ibid.)

What the foregoing makes clear is that there were fundamental differences between the interests, perceptions and expectations of the parties involved - uniquely reflected in the ways they approached the reformation/ modernization of Ottoman order. For the Ottomans, "reforms" meant the restoration of Ottoman power so as to be at least on equal footing with, if not superior to, the European Powers. Indeed, this was a basic strategy of the Ottomans that took shape in the early decades of the 19th century and reached its apogee by the1850s and beyond. This included both modernisation and "Westernisation" of the central State, as well the imposition of effective domination and control on the periphery. Many communities across the Ottoman realm, in turn, regarded reforms as creating conditions of possibility for their gradual emancipation and provided momentum for autonomy, a drive that also became more and more effective following the first decade of the 19th century. The European Great Powers, on the other hand, viewed the reforms as a launch pad for territorial expansion, as well as economic and political penetration, into the Ottoman realm.

The problem was that the Ottoman politics of effective rule played out under conditions where the rules of the game of power politics began to change. As masterfully explained by Wilhelm Grewe in an extensive Study on Epochs of International Law, from the early decade of nineteenth century, the dynamics of power politics and rivalries began to be regulated by "the International Legal Order of the British Age 1815 -1919, with its legal institutions of the new colonial Law of Nations. The age of British predominance rendered the international legal order of the nineteenth century its specific character (GREWE, 2000, p. 429 ff.). The most important feature of this change was expressed in the assertion of the principle of effectiveness that gradually became the regulating norm behind the colonial expansion and associated rivalries among the powers involved. In tracing the origins of this principle during the longue durée of colonisation, Grewe (2000) demonstrates how the older "right of discovery" was replaced by the principle of "effective occupation" that became the standard legal title for the acquisition of colonial territory in the British age. "The new wave of European expansion and taking possession of further colonies, which began in the last quarter of the nineteenth century", Grewe (2000) maintains, "took place against the background of the generally recognised validity of this title" (GREWE, 2000, p. 545). As a result, the law of 'civilised' nations only recognised the property and sovereignty of a nation in unpopulated regions, "if that nation was executing an actual occupation, i.e. founding a settlement and making actual use of it" (GREWE, 2000, p. 399.). 
4. Referring to the establishment of a French protectorate in Tunisia in 1881 , the British occupation of Egypt in 1882, and the Bulgarian annexation of Eastern Rumelia in 1885, historian Hanioğlu observed that all these drew no more than formal protests from the Ottoman government because "Abdülhamid II carefully evaded direct confrontations with the Great Powers and studiously avoided taking risks for regions only nominally under Ottoman control (HANIOGLU, 2008, p. 130)

5. For example: "Between 1899 and 1914 , a total of 86,111 Syrians entered the United States, 90 percent of whom are estimated to have been Christians. Still others went to Latin America where communities of "Turcos" could be found in Sao Paulo, Caracas, Buenos Aires, and Mexico City by the start of the First World War. Syrian Jews also migrated both to the US and Mexico, as well as to Britain. Between 1871 and 1909

60,653 Syrians entered Argentina, the

largest single destination for Syrian immigrants in Latin America. But unlike the pattern of emigration to the US and Mexico, the stream of migrants going to the New World's southern hemisphere was more evenly divided between Mus-

lims and Christians and even included Druzes" (MASTERS, 2001, p. 145).

6. For a very instructive synopsis along with comments on annotated bibliography see AVIV, Efrat. Entry Millet System in the Ottoman Empire. Oxford Islamic Studies, last modified: 28 November 2016. D0I: 10.1093/ OB0/9780195390155-0231
Translated into the code of conduct among the Great Powers, this shift basically meant either effective rule on the territories claimed or the loss of sovereignty over them. The requirement of effectiveness posed a great threat to the Ottoman rule over its possessions, especially over those territories where military and administrative control was but nominal or where a greater degree of autonomy existed. ${ }^{4}$ To conclude, at every critical juncture during the 19th century, the peculiar dynamics of the said trivalent relationship between the European Great power politics, the identity politics of subject peoples and the Ottoman policies of centralising and increasingly nationalising the empire at work. However, in times where these factors came together to act in a zero-sum game manner, the outcomes were the most devastating. This deadly coming together of factors was particularly evident before and during the Russo-Ottoman War (1877-78), the Balkan Wars (1911-1913), and finally World War One (1914-1918).

As will be shown in this paper, all of this fundamentally affected the status and destiny of non-Muslim and Muslim communities alike. One important outcome of this process was the mass migration on the part of non-Muslim communities from the Lebanese mountains and elsewhere to the Americas, including Brazil ${ }^{5}$. As will discussed in more detail below, the Russo-Ottoman war ended with the near collapse of the Ottoman Empire, the Balkan Wars ended with almost complete loss of the empire's European dominions, while World War One caused the Armenian genocide, expulsions and extermination of the Greek and other minorities and, finally, the collapse of the Ottoman Empire itself. In the remainder of this article, I will outline the contentious status of minorities and its evolution along the proposed line of argumentation and will conclude by summarising the main points.

1. Structural Exclusion by Toleration

Ruling over a vast amount of territories with a heterogeneous population made up of diverse groups of people can be regarded as one of the central criteria for the success and survival of any empire. Following the conquest of foreign territories, including the conquest of Constantinople in 1453, where a majority Christian population lived, the Ottomans were faced with the daunting task of having to deal with the sheer diversity of population, territories and ethno-religious communities in the region.

Out of this process emerged elements of what would come to be known as millet (BARKEY, 2008, p. 12). The millet system is widely held as a long-lasting example of a form of non-territorial autonomy and "innovation that Ottoman rulers used to organize the empire's religious groups from the conquest of Constantinople in 1453 to the nineteenth century" (BARKEY; GAVRILIS, 2016 p.24).

Before discussing the meaning and implications of the millet as a politico-administrative system, some terminological clarifications would be appropriate. The term millet is derived from the Arabic word Millah, meaning 'nation' or 'community' (AVIV, 2016) ${ }^{6}$. The idea behind this system stems from the Sharia's (Islamic law) treatment of members of reli- 
gions regarded as People of the Book (Ahal-al-Kitab), that is, followers of religions who believe in the presence of the Almighty. Under the Sharia, the Ahal-al-Kitab could be granted the political status of Dhimmis, whereby they entered into a pact, or Dhimma with the Muslim ruler to accept subordination to Islam, and the requirement to pay a special tax, the Jizya (AVIV, 2016). In Koranic tradition thewere considered as protégés who had to pay additional poll taxes (KIESER, 2019). In short, non-Muslim minorities were tolerated "provided that they accepted their inferior status visà-vis Islam and that they regularly paid their taxes" (LORY, 2015, p. 371).

There is, however, an interesting debate about the initial use of the term Millet, and its application as a ruling technique over subject communities, as well as the scope of the 'system', notably whether or not it was solely restricted to non-Muslims or if it was also applicable to Muslims (TAŞ, 2014, p. 498-526 ff.) ${ }^{7}$. Whilst some scholars show a very receptive disposition towards the merits of the millet (QUER, 2013, p. 79 ff.), others have problematised the sole use of the "millet system paradigm" to describe Ottoman rule over non-Muslim communities (BRAUDE, 1982, p. 70ff; PAPADEMETRIOU, 2015, p. 22). The latter have argued that the millet system was not at all in circulation during the fifteenth and sixteenth centuries, implying that it is rather a late Ottoman conception and can therefore be considered as a "foundation myth" of the Ottoman Empire (BRAUDE, 1982, p.77; DASKALOV; VEZENKOV, 2005, p.6 ff.). However, others maintain that there are earlier references to the millets in the Ottoman tax registers, which indicate that non-Muslim subjects were part of the political-religious vocabulary of the Empire long before they were recognised as autonomous corporations in terms of public law in the 19th century (URSINUS, 1989, p. 202-207).

On a more abstract level, the millet system can be seen as an Ottoman response to the imperative to make heterogeneous populations both legible and governable (BARKEY, 2008, p. 21). Accordingly, the Ottomans were not interested in conducting systematic purification of 'unwanted elements' or indigenous communities of conquered territories. Tolerance, assimilation, and intolerance were thus all on the menu of strategies designed to squeeze resources out of minorities and to enforce allegiance to the imperial state (BARKEY, 2008, p.18). The system allowed rulers "to efficiently organize the empire's population into communities by devolving power to trusted intermediaries and community leaders who in turn were held responsible for governing the community and resolving conflicts both within the community and with other millets" (BARKEY; GAVRILIS, 2016, p. 24). Equally, by giving a degree of recognition as a community with tangible autonomy in the religious and legal realms, irrespective of their place in the empire, the millet system allowed the leaders of communities to act with a sense of confidence, (ibid.). Accordingly, each Millet (the Greek Orthodox, the Catholic, Jewish, and Armenian Millet) was granted autonomy to set its own laws, and to collect and distribute its own taxes (AVIV, 2016).

Placing the treatment of non-Muslims in the Ottoman Empire within the context of Islamic law, Masters maintains that Muslim authorities recognized "the rights of believers in the monotheistic faiths to remain at
7. Contrary to the scholars considering the millet as related only to the non-Muslim communities, Taş (2014) maintains that the Kurds as majority Muslim community used the millet practice as form of fiscal, judicial and administrative autonomy over their region and applied their customary laws over disputes between their members, concluding that the millet practice can be a potential source for plural modern nation-states to draw on in understanding how diversity in a plural society might peacefully be managed as it "offers a unique blend of territorial and non-territorial rights for different communities" (TAS, 2014, p. 498).

8. For example, according Giovanni M. Quer (2013), although the millet system originates from a different legal and political tradition with aspects that may be incompatible with the Western democratic tradition, it can be seen "as a model of diversity management offers available solutions to contemporary multicultural Europe in terms of both collective rights accommodation and formulation of minority and majority groups' interests" (QUER, 2013, p. 79 ff.). 
peace within the umma, as long as they recognized Islam's political authority over them. In the process, this understanding became embodied in the concept of the ahl al-dhimma ("the people of the contract"). This guaranteed the rights of the non-Muslims to property, livelihood, and freedom of worship in return for extra taxes (the jizya) and the promise not to help Islam's enemies" (MASTERS, 2001, p. 20). This understanding gradually became prevalent, and developed into a "concrete legal form in a document known as the "Pact of Umar", a religious code of conduct, indicating both the social marginalisation and political subordination of non-Muslims along with their protection to that effect (MASTERS, 2001, p. 22).

As far as its application to non-Muslim minorities was concerned, the millet was constructed in non-territorial terms. The 'autonomy' was then granted on the basis of religious affiliation and not on a regional or territorial basis. The leader of each religious community was obliged to undertake responsibility for the actions of his community and was directly answerable to the government. It is maintained that in the case of the Greek (Rum milleti), for example, the Ottomans saw the Greek Orthodox ecclesiastical hierarchy as a resource for generating cash income. They primarily became known as tax farmers (mültezim) for cash income derived from the Church's widespread holdings. The Ottoman state granted individuals the right to take their positions as hierarchs in return for yearly payments to the state (PAPADEMETRIOU, 2015, p. 3). On that view, the Church was considered by the Ottomans as a fiscal institution within the larger Ottoman economic and social context (PAPADEMETRIOU, 2015, p. 6). Accordingly, the organisation of millet was designed to act as an effective way of tax collection, as well as an instrument for shaping intra-communal power relations and reproducing subordination and hierarchies: "Time and again, the Ottoman state responded to requests from petitioning clergy by coming to their aid, and using the state's coercive authority, to make sure that the payments were made" (PAPADEMETRIOU, 2015, p. 4).

The millets as constituted in the nineteenth century were hierarchically organized religious bodies with a decidedly political function. Each millet was headed by a cleric, otherwise known as the patriarch or chief rabbi, or in Ottoman Turkish, the millet başı. Although the millet başı were appointed by the sultan, and were required to be resident in Istanbul, they were largely free to order the affairs of their community as long as they remained loyal to the sultan (MASTERS, 2001, p. 61). As the millet involved a "series of arrangements, varying in time and place, that afforded each of the major religious communities a degree of legal autonomy and authority" (BRAUDE, 2014, 16). it can be concluded that the millet was not a firmly established structure endowed with binding and predictable norms, but rather it was a variable technique of governance, premised on a set of arrangements that were periodically negotiated, renewed and enacted, and were always subject to shifting dynamics of power between the respective leaders of each community and the imperial state. What rendered the millet regulation both striking and unstable was its combination of elements of indirect rule with elements of direct rule. Bearing in mind the inherently contradictory nature of both modes of rule, the 
millet formation by and large offered a viable scheme of protection under the Muslim rule, to be sure, at the expense of structural inequality, marginalisation and exclusion from the central areas of the imperial polity. Though important in its historical context, the millet can hardly be seen as a normative exercise in tolerance and recognition with enduring and inspiring features for the present-day quest for conflict resolution. If anything, the millet needs a very critical reconstruction, and reappropriation in light of the development of international law and democratic principles.

However divergent the views on the origins, meanings and implications of the millet are, one thing is certain: it first rose to prominence during the Tanzimat period. It was during this period that the millet became established as way of addressing the rights and legal status of non-Muslim confessional groups, while simultaneously giving rise to the formation of new communities in the mode of the millet organisation. The immediate causes and outcome of this process are the subject of the next section.

\section{Integration through Politics of Recognition (Tanzimat Period)}

In the Ottoman studies Tanzimat (lit. reorganization) era is commonly referred to as the "westernisation" and "modernisation" of the educational, military and political structures of the Empire (THE OXFORD DICTIONARY OF ISLAM, 2003, Tanzimat entry). It was during this period that major reforms were enacted calling for equality for all Ottoman subjects. These reforms resulted in the codified millet autonomy in relation to non-Muslim minorities for the first time. In terms of the status of non-Muslim minorities, two major imperial edicts are of significant importance. The first was the Gülhane Prescript of 1839, named after the park where it was first read, and second the Reform Edict of 1856 (Hatt- $\ddot{u}$ Humayün). In general, both documents are often cited as a hallmark of the religious pluralism within the Ottoman Empire, demonstrating the protection of the rights of all subjects, regardless of religious creed, despite the state's affiliation with Islam (THE OXFORD DICTIONARY OF ISLAM, 2003, Tanzimat entry). In what follows, I shall examine the significance and implications of both documents in some detail.

The Gülhane Prescript was a declaration of intention, outlining a regime of political and legal equality between Christians and Muslims (GINGERAS, 2009, p. 19) ${ }^{9}$. The Hatt-ü Humayun draws on the first but took a more radical step towards equal treatment and civil rights by granting non-Muslim minorities the right to constitute themselves as self-governing entities with its own constitution (nizâmnâme) and an elected assembly. This represented a major change that affected the Rûm millet (Greek-Orthodox), the Armenian millet, the Christian millet (both Protestant and Catholic), as well as the Jewish millet. Excluded from this scheme, however, were the Nestorian Syriacs (Asuri), Syriac Christians (Süryani), Yezidis as well as other non-Muslim minorities (KIESER, 2019, p. 3).

The internal rules of the millets were subject to periodic review by the central government and an assembly to be composed of the community's clerics and laity, creating a potential for future democratization of millet governance, seeing by some clergy as undermining their authori-
9. Hatt-i Şerif (the Noble Prescript of Gülhane) made as part of Ottoman reforms protected the rights and property of subjects, affirmed the restoration of Sharia as law; instituted protections of life, honor, and property; fixed taxation according to wealth; granted all subjects the right to public trial and verdict; promised an even distribution of military service across the population; and extended rights to all subjects, whether Muslim or non-Muslim. 
10. "The spark that set off the Aleppo riot of 1850", according to Sharkey, "was a report that spread among Muslims of the eastern quarters, to the effect that Ottoman authorities were about to impose a new military draft. Making matters worse was the new Ottoman policy of taxing Muslims directly" (SHARKEY, 2017, p. 147) Similarly, Masters (2001) notes how, the "[v]iolence targeting foreign or domestic Christians took place in Aleppo in 1850, Mosul in 1854, Nablus in 1856, Jeddah in 1858, and Egypt in 1882. Muslim anger could also be directed at Jews, as occurred in the Mosul riot or in Baghdad in 1889. But across the region, the descent into sectarian violence served to segregate Muslims from Christians, rather than pit Muslims against al non-Muslims indiscriminately as the

Christians had become associated with the most obvious manifestations of change" (MASTERS, 2001, p. 130). ty” (MASTERS, 2001, p. $138 \mathrm{ff}$.). This politics of millets was also motivated by a fine-tuned policy of divide and rule, aimed at augmenting the extraction of resources and keeping the communities manageable, whilst counteracting the growing Tsarist Russian influence over the Orthodox Christian communities across the Balkans and elsewhere.

The reform edicts led to the formation of new millets, and "further encouraged Christian elites to articulate and refine religious identity as a means to obtain political power" (MASTERS, 2001, p. 61). Alongside the already existing millets mentioned above, new millet structures, namely the Uniate Armenian (1831) and Melkite Catholics (1848) and Protestant Millet (1847), were established and recognised, leading smaller and formerly less active Christian sects to take their success as a model.

The declaration of Muslim-Christian equality created confusion and discontent, resulting in gradual replacement of the millet system by a more uniform code of law and civic responsibility (GINGERAS, 2009, p. 19). Faced with the challenge of nationalism and ensuing disintegration of the Empire, Istanbul attempted to defuse them by creating a new patriotic identity, that is, the Ottoman identity based on dynastic and imperial allegiance. For this purpose, in January 1869 a law entitled "nationality or citizenship law" (Tabiiyet Kanunu) was passed, stating that "all individuals born of an Ottoman father and an Ottoman mother, or only an Ottoman father, are Ottoman subjects" (AHMAD, 2014, p. 3-4).

Although prerogatives and privileges seen as the preserve of Muslims communities remained largely unchanged (GINGERAS, 2009, p. 19), the reforms nonetheless resulted in the empowerment of national-religious communities, and gave rise to the assertion of communal aspirations towards more emancipation which was in turn deemed by many as a threat to the predominant pattern of relations. Both reform edicts were perceived as "dismantl[ing] the legal hierarchy governing the relations between Muslims and non-Muslims established by the Pact of Umar with the blunt justification that such steps were necessary to save the empire" (MASTERS, 2001, p. 137). Indeed many saw the reforms as exacerbating the economic crisis of the Ottoman empire, fostering its dependency on European loans, while failing to stifle ethnic and religious separatism encouraged by Great Britain and France, and provoked unrest among Muslims (HANIOĞLU, 2008, p.110). A large number of people also viewed the reforms as empowering the non-Muslim communities, at the expense of their own situation. The growing sectarian antagonism led to violent outbursts across the imperial domains. The most tragic among them occurred in Aleppo 1850 and in 1860 with the civil war in Lebanon and the subsequent Damascus riot. ${ }^{10}$ The violent nature of these clashes has been described by historian Sharkey who notes that "the 1860 Maronite-Druze skirmishes escalated into massacres, including one that killed 5,000 people on a single day in July" (SHARKEY, 2017, p. 150)

Sharkey (2017) also emphasizes how the intercommunal violence sprang "from the collapse of the feudal order, changes in Ottoman policies, shifts in the local economy, and the rising tide of sectarianism as factors that mixed together and exploded" (SHARKEY, 2017, p. 150). However, despite the situation 'exploding' it is important to note here, 
as Masters (2001) suggests that "it was not so much equality with the non-Muslims, that the Muslims were protesting, but their perception that the Christians were now in the ascendancy" (MASTERS, 2001, p. 132).

Moreover, the communal empowerment and the increasing visibility of communities in terms of building new churches, holding public religious processions, and vaunting their connections to the militarily dominant Europeans that had once existed largely outside the public gaze of Muslims "rubbed salt into the Muslims' psychological wound" (ibid.). The result was an increasing politicisation of religion and promotion of sectarianism. This was elevated to a basic strategy of the Ottoman politics once the Russo-Ottoman War of 1877-78 broke out. This war once more changed the entire geopolitical landscape of the empire in fundamental ways, and fateful effects on the fortunes of non-Muslims and Muslims alike. One important outcome of the war was the ascendancy of Sultan Abdülhamid II (1842-1918) to power.

3. Control and Coercive Domination (Hamidian Period, 1876-1909)

If reactions against granting equal treatment and equality before the law were still somehow manageable throughout the Tanzimat period, the Russo-Ottoman War of 1877-78 not only led to the reversal of the reform legislation, but also to the rise of a deeply suspicious and hostile politics, especially towards Orthodox communities. The war indeed marked a watershed moment in the last quarter of 19th century of the Ottoman empire, creating new geopolitical realities, while shifting the balance of power on an unprecedented scale.

In April 1877, Russia declared war on the Ottoman Empire following an agreement, signed in mid-January, with Austria-Hungary that allowed Russia freedom of movement in the Balkans in exchange for Austro-Hungarian rule over Bosnia and Herzegovina (FORTNA, 2008, p. 46). The war took place against a background of a peasant rebellion against Ottoman rule in the Balkans in 1875 . In July 1885, Slav peasants revolted against their Muslim landowners in Herzegovina followed by a fresh rebellion in Bulgaria that took place in April 1876. In July 1876, Serbia and Montenegro declared war on the Ottoman state (HANIOĞLU, 2008, p. 111). Of course, Russia, keen to exploit the weaknesses of the Ottoman Empire, as it had done for centuries at many critical junctures in the empire's history, was quick to support the rebellion by taking the lead in the war.

The Russo-Ottoman war of 1877-78 turned out to be a disaster for the Ottomans. The San Stefano Treaty of March 3, 1878 marked the high point of Russian expansion at the expense of the Ottoman Empire. "Not only did the treaty award Russia certain territorial gains, it granted independence and additional territory to the ostensibly Ottoman states of Montenegro, Rumania, and Serbia" (HANIOĞLU, 2008, p. 121). The treaty also sanctioned

\footnotetext{
"internal reforms in various Ottoman areas, including Armenia; and a massive financial indemnity to Russia causing continuing exodus of Muslim refugees from lost territory into the shrunken borders of the Ottoman Empire, forcing the state to use scarce funds to feed and shelter them" (FORTNA, 2008, p. 46).
} 
In defeat, the Ottomans were forced to make major concessions to Bulgaria in March 1878 as part of the Treaty of San Stefano, which established a "greater Bulgaria" that extended from the Black Sea to the Aegean Sea. Alarmed by these Russian gains, Britain, Austria-Hungary, and Germany intervened in favour of the Ottomans and compelled Russia to revoke some of the concessions imposed on the Ottomans, which forced Russia to withdraw from Ottoman territories. As Mann notes, "[s] ome were declared independent states, and others were given to Austria in order to preserve the Balkan balance of power" (MANN, 2012A, p. 281). Although Bulgaria became autonomous, it was reduced in size and divided into two parts. Macedonia remained within the confines of the Ottoman Empire, whereas Serbia and Montenegro were recognized as sovereign states (AHMAD, 2014, p. 5).

The Congress of Berlin in 1878 "created a Bulgaria that was autonomous but tributary and an Eastern Rumelia that was semi-autonomous, with a Christian governor who was to be appointed by the Ottoman government" (KASABA, 2004, p. 46). Historian Todorova notes that not only were the size, shape, stages of growth of the different Balkan states almost exclusively regulated by great power considerations with regards to "the rules of the balance-of-power game" but so too was their very existence. (TODOROVA, 2009, p. 169). The impact of the war and subsequent treaty for the Ottomans was huge as Keyder (1997) observes,

\footnotetext{
"Balkan nationalism culminated in a massive loss of territory following the 187778 war with Russia. The empire lost more than a third of its lands, especially the provinces where its non-Muslim population had constituted the majority. Social and economic conditions shifted radically, as did the causes of the empire's dismantling" (KEYDER, 1997, p. 33).
}

One important outcome of the war was the dissolution of the newly established Ottoman parliament in February 1878. Sultan Abdülhamid used the war with Russia as a pretext to suspend the constitution, introduced on 23 December 1876, for the next thirty years. Under the constitution all Ottomans would become equal before the law, enjoying the same rights and obligations regardless of ethnicity or religion, though Islam remained the religion of the state (AHMAD, 2014, p. 5). Following the dissolution of the parliament, the sultan began to construct new methods of administration by promoting an efficient bureaucracy in control of the periphery, reinstating an old Ottoman emphasis on personal loyalty on the parts of bureaucrats "as an indispensable qualification for employment in the civil service” (HANIOGLU, 2008, p. 123 ff.). During his reign Pan-Islamism became established as a guiding strategy which transformed "a religio-political instinct into a politico-religious policy” (BRAUDE, 2014, p. 47). The aim was twofold: first, to mould the Muslim elements of the empire into a cohesive whole in order to build a core identity, a policy that was also facilitated by enormous demographic change brought about by the loss of territory heavily populated by Christians, and the influx of Muslim refugees, which increased the Muslim proportion of the Ottoman population to 73.3 percent. The second aim was the "use of Pan-Islamic propaganda as a wild card directed against colonial powers who ruled over substantial Muslim populations" (HANIOĞLU, 2008, p. 130). 
Sultan Abdulhamid embarked on an ambitious set of policies towards centralising and regularising the control of the central government, modernising the armed forces and education system, and creating a loyal elite (FORTNA, 2008, p. 48). He was particularly concerned with strategic infrastructure projects, such as internal communications and the railway infrastructure "that would improve the efficiency of the Ottoman army and facilitate greater control over the imperial peripheries as well as investment in a widespread intelligence network" (BLOXHAM, 2005, p.46). Conflicts in the Balkans and the consequent Ottoman-Russian War led to dramatic territorial losses for the Ottoman Empire in the Balkans, the Caucasus and the entirety of Cyprus. As a consequence, Abdülhamid considered the political principles of the preceding reform period a failure and instead implemented policies designed to empower the (Sunni) Muslims and to assimilate the Alevis, Yezidis and Shiites. This was because "the empire increasingly considered Asia Minor its core land given the territorial losses of previous decades" (KIESER, 2019. p. 3).

One crucial development during the Hamidian regime was the emergence of the Armenian national movement, namely the two revolutionary parties, Hunchak ("The Bell”) and Dashnaktsutyun (the Armenian Revolutionary Federation, ARF) (FORTNA, 2008, p. 54). The Armenian nationalist political parties were established "in the late 1880s in the comparative safety of Russian Armenia at about the same time as organized constitutionalist Muslim groups were being formed in opposition to $\mathrm{Ab}$ dulhamid's autocratic rule" (BLOXHAM, 2005, p. 49). As Bloxham indicates in the early 1890 s, "the parties, particularly the Hunchaks, infiltrated Ottoman Armenia to coordinate revolutionary activity and import arms. Following the model of Bulgarian nationalists, the Huncak led the movement to recapture the attention of the powers, sometimes by ostentatious, terrorist methods and assassinations that also reveal a debt to the Russian populists" (BLOXHAM, 2005, p. 50). Thus, we can see how at this time, in order to divert attention to the Armenian plight "Armenian revolutionaries stepped up acts of violence and sabotage in the hope of provoking European intervention" (HANIOĞLU, 2008, p. 131).

The overall situation led to the "Hamidian massacres", a series of atrocities carried out by Ottoman forces and Muslim irregulars against the Armenians in the Ottoman Empire between 1894 and 1896. The Ottoman authorities increased their repression of Armenians, raised taxes on Armenian villages, and aroused nationalistic feelings and resentment against Armenians among the neighbouring Kurds. When, in 1894, the Armenians in the Sasun region refused to pay an oppressive tax, Ottoman troops and Kurdish tribesmen killed thousands of them and burned their villages. Another wave of killing began in September 1895, when the Ottoman authorities' repression of an Armenian protest in Istanbul turned into a massacre. The incident was followed by a series of massacres in towns with Armenian communities that culminated in December 1895, when nearly 3,000 Armenians who had taken refuge in the cathedral of Urfa (modern Şanliurfa) were burned alive (BLOXHAM, 2005, p. 67). "Tragically for the Armenians", Braude concludes, "their hopes for national independence arose at the end of a century-long succession of 
Christian uprisings in the Balkans. And their aspirations were centered in Anatolian territory that the leaders of the Ottoman Empire in its last decades came to regard as the last bastion of what remained of their empire” (BRAUDE, 2014, p. 36).

Thus, the Russo-Ottoman War created the conditions under which Armenian aspirations for communal emancipation was responded to with state-organised mass violence. The violence was organised by an Empire that was continuously in pursuit of a more centralising, homogenising and nationalising form of Pan-Islamist politics, and was accompanied by increasingly radicalised national movements, with the European Powers unwilling to take effective diplomatic and political initiatives in order to stop the plight of the Armenian community or to prevent the escalation of the conflict. Such was the background against which the İttihat ve Terakki Cemiyeti (Committee of Union and Progress, CUP), otherwise known as the Young Turks, took over the state power in 1908.

4. Politics of nation-building by communal extermination and expulsion (CUP Rule, 1908-18)

Tilly's dictum "war made the state and the state made war" provides a powerful metaphor to think about the post-World War I geopolitical constellations in the post-Ottoman geography in general, and for the geopolitical situation of minorities in particular. The European Great Powers' politics towards the Ottoman empire, the ever increasing level of national conflicts in the Balkans, and the Ottoman politics of centralisation and homogenisation entered into a completely new era with the ascendancy of the Turkish nationalist movement, the Committee for Union and Progress (CUP), culminating in a military coup in 1908.

For a while, the removal of the Abdülhamid regime and ensuing reinstitution of the constitution, which was suspended in February 1878 on the pretext of the Russo-Ottoman war, was met with hope and a sense of optimism. But the constitution that was supported by all in the days of the revolution was soon "used against many to eradicate traditional privileges in the name of equality before the law, and to threaten the very fabric of millet communities amid the denigration of the the millet institutions as "government within the government" (SOHRABI, 2018, p. $844 \mathrm{ff}$.). Contrary to its promises for more democratic and inclusive governance, the CUP proceeded to reinforce a nationalist politics based on "eradication of difference", pushing a multiethnic state towards becoming "an imperial nation-state" (SOHRABI, 2018, p. 844).

The more the Young Turks established their power grip on the Ottoman state apparatus, the less they were inclined to introduce reforms and to address the aspirations of other nationalities. The dictatorial rule of the CUP was then confronted with an upsurge in national insurgencies initially from the Balkan peoples. The overall situation was exacerbated by the interventions of the Great Powers on behalf of one or another party to the conflicts. The key ingredients of this conflict escalation - the politics of the Great Powers, the politics of the nationalising elite of the Ottoman state, and the politics of national independence of subject peo- 
ples - were once again at work, coming together to produce the most disastrous consequences. The murderous dynamics of conflict escalation worked to their fullest on the cusp of the Balkan Wars (8 October 1912 - 18 July 1913). Just one year after Italy's invasion of Libya, the armies of Bulgaria, Greece, Serbia, and Montenegro attacked the Ottoman forces in a concerted effort to gain independence from the Ottoman empire. The first of the Balkan Wars led to the partitioning of Ottoman Macedonia and Thrace by the Balkan States, further causing Albania's declaration of independence (GINGERAS, 2016, p.56).

The outcomes of these events were immeasurably devastating. The Ottomans suffered huge losses in the Balkan Wars, losing 83 percent of its territory, and 69 percent of its population in the European provinces. Most of its Muslim population was left behind, and many fled to Anatolia. Muslims were the majority community in the Ottoman Balkans before the war began, and were the largest single religious community $\mathrm{AH}$ MAD, 2014, p. 46; GINGERAS, 2016, p. 56). The loss of Rumeli, seen as the empire's keystone and the cradle of the CUP, radicalized and scarred the country's leadership permanently. The Balkan Wars brought about "the greatest mass migration in the empire's history and produced legacies of the conflict that would continue to linger well into the Great War and beyond" (GINGERAS, 2016, p.56).

The Balkan disasters in combination with the CUP's decision to take part in the First World War fundamentally altered the parameters of the imperial politics and polity. This shift was reflected both in mindset and in the public policies of the CUP leadership. The war was seen as opportunity by the CUP leadership (AKSAKAL, 2008, p. 179ff.), especially the alliance with Germany which was regarded "as a desirable path to reclaiming the empire's independence and economic stability" (AKSAKAL, 2008, p. 190). In March of 1914, the Young Turks then entered World War One on the side of the Central Powers (Germany, Austria-Hungary, and Bulgaria). They attacked to the east, with the aim of capturing the city of Baku as part of the Caucasus campaign against Russian forces in the Caucuses. "The whole of the war in the Near East and the Balkans", observes Bloxham, "was drawn along ethnic-national lines and every imperial power was seeking advantage in their opponents' territory by offering incentives to nascent ethnic/religious/nationalist movements therein" (BLOXHAM, 2005, p. 94). Accordingly, the locus of ethnic conflict spread fully into the Caucasus, where it had long been simmering. Germany coveted the mineral resources of the Caucasus for the sustenance of its war effort, while the door had reopened in an unlikely fashion for the pursuit of the CUP's expansionist ambitions (BLOXHAM, 2005, p. 100.).

The pan-Turanian and pan-Islamic campaigns conducted in the Caucasus, in Persia, and the Arab lands respectively "miscalculated the effect of Ottoman propaganda on other Turkic and Muslim peoples" (BLOXHAM, 2005, p. 69). The politics of expansion led to a disastrous defeat at the battle of Sarikamish (December 1914/January 1915). "In early 1915”, notes historian David Fromkin, "Enver, as Minister of War, and Talaat, as Minister of the Interior, claimed that the Armenians were openly supporting Russia. In reprisal they ordered the deportation of the entire 
Armenian population from the northeastern provinces to locations outside of Anatolia" (FROMKIN, 2001, p. 212). The treatment of the Armenians was particularly brutal as "[r]ape and beating were commonplace. Those who were not killed at once were driven through mountains and deserts without food, drink or shelter. Hundreds of thousands of Armenians eventually succumbed or were killed" (FROMKIN, 2001, p. 212).

The systematic killings and deportations during the War led to the total destruction of the Armenian people of the Ottoman Empire (MELSON, 1992, p. 29ff.). Referring to the politics of the CUP, the Austro-Hungarian Ambassador Johann von Pallavicini in a diplomatic dispatch, dated 7 Nov. 1915, described the policy of the CUP as a means of 'creating a national state through the annihilation of foreign elements' (PALLAVICINI apud BLOXHAM, 2005, p. 94). Many scholars have explained how the mass killing in the late Ottoman empire, and the Armenian genocide as causally related to the logic of nation-building, the national security strategies of nationalising and homogenising elites, and the politics of national and cultural homogenisation in the context of world war marked by rivalries among the great powers (MYLONAS, 2012, p. 48; AKÇAM, 2004, p. 44; GÖÇEK, 2011, p. 52).

The CUP increasingly saw "the Ottoman entity as ethnically single rather than as a diverse multiplicity of peoples while defining loyalty to the state as function of supposed ethnic reliability" (LEVENE, 2014, p. 4, Volume). With the outbreak of the First World War, the Great Powers' designs on the Ottoman Empire intensified, as was "the Ottomans' ambition to create a homogeneous state on the basis of either ethnicity or religion, through a Pan-Turkic and Pan-Islamic expansionist policy" (AKÇAM, 2004, p. 21). Accordingly, as long as Anatolia remained ethnically pluralistic, "it would be vulnerable to subversion and partition", a mindset leading the CUP to conclude that the "homogenization of Anatolia was the surest solution to the dilemma they faced" (REYNOLDS, 2011, p 150). This led to both the extermination of the Armenians and the state-guided demographic transformation of Eastern Anatolia which included Muslim Kurds, Albanians, Circassians (REYNOLDS, 2011, p. 149).

Bloxham (2005) has emphasised how "the complexities and contingencies of state policy-making in a period of prolonged wartime crisis" are more relevant to the understanding of the Armenian genocide than a prior genocidal intent. The Armenian case is thus best understood as "a process of cumulative radicalization towards a policy of genocide, a radicalization with its roots in the interaction of great power imperialism, Near Eastern nationalism, and the decline of the Ottoman Empire" (BLOXHAM, 2005 , p. 96). The cumulative use of mass murder was maintained by "the intimate relationship between intention and contingency" (ib. 2005, p. 63). The genocide is then explained as emerging "from a series of more limited measures implemented regionally that developed into an empire-wide programme through a process of cumulative policy radicalization which, in the early summer of 1915, culminated in an policy of general killing and death by attrition" (BLOXHAM, 2005, p. 69). The Armenian Genocide, along with the killing of Assyrians and the expulsion of the Anatolian Greeks, laid the groundwork for the more homogeneous nation-state that emerged from the ashes of the empire (SUNY, 2011, p. 41). 
Taken together, the Balkan Wars and World War One provided the conditions, opportunities and expediencies for the CUP regime to execute its politics of state transformation and nation-building through national, religious and cultural homogenisation of a multicommunial and multicultural Empire by genocidal violence. I refer to this particular politics and its outcomes as "nation-building by nation-destruction"11 to indicate the processes and policies of extermination and expulsion of communities by state-organised political violence, a violence that resulted from the generation of new forms of state power seeking to homogenise societies, if deemed necessary, by resorting to ethnic cleansing and genocide (BLOXHAM; GERWARTH, 2011, p.3; BLOXHAM; MOSES, 2011, p. $138 \mathrm{ff}$.).

The concept of "nation-building by nation-destruction" is intended to combine the contrasting aspects, namely the "regenerative" and destructive nature, of this process of nation-building in an instructive dialectical concept. My argument is that this conceptualisation may shed some light on the complexities of this matter, and lead to a better understanding of some of the processes and policies of state formation and nation-building in many other places. If that is the case, this concept would allow us to study the dual character of the process without being trapped into affirmative positions or reducing the inherently destructive features of such policies to the level of intended consequences along an unavoidable path of national modernization and regeneration.

Conclusions and Discussion

This essay has examined the situation and status of non-Muslim communities within the Ottoman Empire by offering a periodisation to examine commonalities and differences as well as changes and continuities. The periods have been defined as structural exclusion by toleration, Integration by a politics of recognition of difference (Tanzimat Phase, 18381876), coercive domination and control (Hamidian Period, 1876-1908), politics of nation-building by nation-destruction (the CUP period, 1908-1918). This periodisation has proven to be of explanatory value in terms of identifying the dominant mechanism within each period, while establishing relationships among the periods as they shifted from one to another. The periodisation, however, is not meant to suggest that outcomes were inevitable and that the shift from one period to another was predetermined. Rather, it is referred to as an heuristic device to more precisely understand the salient features of Ottoman policies towards the subject non-Muslim communities.

My focus has been on non-Muslim minorities, yet the elements of this framework can equally be applied to the non-Turkish but Muslim peoples such as the Kurds and others. The post-Ottoman Turkish state, the "Republic of Turkey" (1923), did not only emerge out the ashes of the Ottoman Empire, but more fundamentally founded on the institutional and ideological framework together with its core military, bureaucratic and administrative staff as well as policy paradigmas laid out by the CUP regime (BEZWAN, 2008, p. 138 ff.).
11. The idea of "nation-building by nation-destruction" draws its inspiration from Connor Walker's argument that reads as follows: "Since most of the less developed states contain a number of nations and since the transfer of primary allegiance from these nations to the state is generally considered the sine qua non of successful integration", Walker maintains, "the true goal is not 'nation-building' but 'nation-destroying'" (WALKER, 1994, p. 42.). I am paraphrasing this idea as "nation-building by nation-destruction", widening its scope to include not just less developed states, but developed ones too. 
12. Referring to the argument of the state continuity between the Ottoman Empire and the Turkish Republic, ÖKTEM maintains that the concept of the continuing state differs from that of the successor state, emphasising that the former is not only "entitled to the predecessor's rights, but is also bound by the predecessor's obligations" (2011, p. 581). The Ottoman legacy, he laconically adds, "is a Pandora's box that may unveil all kinds of surprises" (ibid.)
Since its inception in 1923, the successive governments of the Turkish republic (i.e. the legal and political successors of the dissolved Ottoman Empire $)^{12}$ have, to varying degrees, adopted elements of CUP politics of nation-building by nation-destruction. With the extermination and expulsion of Christian communities from Anatolia, except for a small Jewish community and tiny Christian groups in and around Istanbul, there were non-Muslims left to be targeted. There were instead mainly Muslim communities, such the Kurds and others, to them the politics of negation and forced assimilation through the use of state-organised mass violence turned. It is beyond the scope of this article to address this question but suffice it to say that this fact lies at the roots of many fundamental problems of which Turkey is today faced.

In Remapping the Ottoman Middle East, a meritorious and nicely framed study, Cem Emrence (2011) suggests that the Ottoman Middle East is essentially defined by three historical trajectories during the nineteenth century:

\footnotetext{
"the coast, the interior, and the frontier. The coastal framework represented the port-cities and commercial hinterlands of western Anatolia and the eastern Mediterranean littoral; the interior path marked the inland experience of Anatolia, Syria and Palestine; and the frontier incorporated the contentious borderland regions of eastern Anatolia, Iraq and the Arabian Peninsula” (EMRENCE, 2011, p. 4).
}

These trajectories produced long-term outcomes, with "economy on the coast, politics in the interior, and contention in the frontier served as primary processes that initiated regional paths in the late Ottoman Empire" (EMRENCE, 2011, p. 4). While the coast became the spatial seat of modernity, embodying middle-class values, global interactions, and a broad public sphere, state-led transformation and conservative values dominated the inland regions where the legitimacy of the state and moral values of Sunni Islam characterized the interior. In the frontiers, in turn, geopolitical competition blocked the path to successful state-building, allowing the local interests to bargain effectively with the central state for autonomy (EMRENCE, 2011, p. 7). This state of affairs is then expressed in socially and materially distinct political geographies during the nineteenth century with different developmental and institutional outcomes. This ranges from thin rule in the arid frontiers where rural religious networks operating on protection rents clashed with the Ottoman state over centralization, to contested rule on the coast where non-Muslim middle classes enjoyed the spoils of foreign trade and European services, but with limited political leverage with the Ottoman state, to consensual rule in the interior "where the unrivalled hegemony of the late Ottoman state was backed up by bureaucratic institutions, domestic markets, and a powerful Sunni bloc" (EMRENCE, 2011, p. 6-7).

This paper has demonstrated that Ottoman policies and practices towards different subject communities were ultimately determined by the coercive capacity of the state and its intersectionality with exigencies and expediencies of the balance of power under each prevailing and ever-shifting geopolitical circumstances at a given historical juncture. In other words, a general reference to the 'thinness' and 'thickness' of the Ottoman rule in a given region is not self-explanatory, and indeed can be 
misleading when it comes to explaining both the rationale behind Ottoman policies and its historical outcomes. The article has shown that the majority of the cases of mass violence, for example, was planned and executed by the Ottoman authorities along with the power of mass mobilization of the distressed, loyal or potentially very influenceable segments of the mainly Muslim population. This occurred not because the region in question was thinly ruled, but because of an interplay of factors - among them the coercive capacity of the state, the mobilisational of power and the opportunity structures provided by the context of war - which have always been determinant. As has been shown, even in instances where the lack of authority seems to have played a role in intercommunal conflicts, notably the mass violence in the Fertile Crescent, Aleppo (1850) and in Mount Lebanon and Damascus (1860), the real, or perceived effects of state consolidation and policies are strikingly present (MASTERS, 2001, p. 132ff; SHARKEY, 2017, p. 150ff.). ${ }^{13}$

By state coercive capacity, I mean the sanctioning power of managing military conscription, collection of tax revenues, collective actions on the part of the subject communities and communal relations between them, while counteracting the encroachments of the rival European pow$\mathrm{ers}^{14}$. Bearing in mind that the balance of power produced both constraining and enabling effects on the Ottoman politics, this paper highlights the importance of focusing on the ways and means by which the state coercive capacity was put into action, the specific historical circumstances under which it was enacted, and finally, the opportunity structure, as provided by the balance of power among the external and internal actors involved in the process, under which it was executed.

In an article on The Ottoman Legacy in the Balkans historian Bernard Lory (2015) has rightly emphasized that rather than producing a discourse of identity and/or discourse of rejection history as a discipline of the mind, and historical narrative should be more inclusive (LORY, 2015, p. 405). Bearing that in mind, I believe that one way of promoting an inclusive perspective on the Ottoman history is a non-Orientalised and yet critical, reflective and relational approach towards the Ottoman legacies and the politics of nation-states emerging out of the dissolution of the Ottoman empire, be they in the Balkans or in the Middle East. In this study, I have attempted to establish a case for a non-Orientalised decolonial approach to the study of the Ottoman empire, and the nation-states constructed in the post-Ottoman political geographies. I use the term "decolonial" both in the sense of political and societal emancipation, and of deconstructing state-engineered official historiographies/ideologies that affirm or justify the authoritarian legacies, injustices and oppressions in the past and present. It is thus best understood as a epistemic disobedience against what Spivak called "epistemic violence" that constitutes "the colonial subject as Other" and "the asymmetrical obliteration of the trace of that Other in its precarious Subjectivity" (SPIVAK, 2010, p. 35). It is this violence that is "exerted against or through knowledge" by means of using epistemic frameworks that legitimise and enshrine the practices of domination (GALVÁN-ÁLVAREZ, 2010, p.12).

I therefore hope that this paper has been able to provide some ideas and arguments for an approach towards a non-Orientalised decolonial un-
13. Having said that, this is not to suggest that the Muslim communities (Turks, Kurds, Arabs, Circassians and others) are to be excused from committing violent actions and or taking part in massacres conducted against various non Muslim communities over the course the Tanzimat period to the Hamidian to the Young Turks. "The spark that set off the Aleppo riot of 1850, Historian Sharkey, "was a report that spread among Muslims of the eastern quarters, to the effect that Ottoman authorities were about to impose a new military draft. Making matters worse was the new Ottoman policy of taxing Muslims directly "(SHARKEY, 2017, p. 147). Violence targeting foreign or domestic Christians took place in Aleppo in 1850, Mosul in 1854, Nablus in 1856, Jeddah in 1858, and Egypt in 1882. Muslim anger could also be directed at Jews, as occurred in the Mosul riot or in Baghdad in 1889. But across the region, the descent into sectarian violence served to segregate Muslims from Christians, rather than pit Muslims against all non-Muslims indiscriminately as the Christians had become associated with the most obvious manifestations of change" (MASTERS, 2001, p. 130).

14. In the recent literature the concept of state capacity is taken to mean "extractive, coercive, and administrative capacity" (WHITE, 2018, p,130), which is built on the works of two scholars, Michael Mann and Theda Skocpol. The latter had argued that general components of state capacity can be identified as "the stable administrative-military control of a given territory", "loyal and skilled officials" and "plentiful financial resources" (1985, p. 16). Mann in turn makes distinction between two basic forms state power with different combinations of strengths: first, "despotic power, the range of actions that the state elite is empowered to make without consultation with civil society groups; and second, infrastructural power, the capacity of the state to actually penetrate civil society and implement its actions across its territories (MANN, 2008, p. 355). Despotic power refers to the ability of state elites to make arbitrary decisions without consultation with the representatives of major civil society groups. Infrastructural power in turn is the capacity of a state, whether despotic or democratic, to actually penetrate society and implement logistically political decisions throughout the realm and thus enabling states to diffuse their power through or penetrate their societies, while the exercise of despotic power is by a state that has a degree of authoritative "power over" society. So states may be strong in either of two quite different ways (MANN, 2012B, p.13). 
15. DERINGIL, Selim. They live in a state of nomadism and savagery: the late Ottoman Empire and the post-colonial debate, Comparative Studies in Society and History, 45, 2, 2003, pp. 311-42. See also KÜHN, Thomas. An imperial borderland as colony: knowledge production and the elaboration of difference in Ottoman Yemen, 1872-1918 The MIT Electronic Journal of Middle East Studies, 3, Spring 2003, pp. 5-17; Eldem, Ethem. The Ottoman Empire and Orientalism: An Awkward Relationship, in After Orientalism. Critical Perspectives on Western Agency and Eastern Re-appropriations, Brill, Leiden Studies in Islam and Society, Volume 2, 2015 , pp. 89-102

In an inspiring article on Ottoman Orientalism, Maksidi (2002) has rightly emphasized that for the most part, "studies of Orientalism have focused on how Europeans have represented the Orient, or how Eastern societies (Ottomans and others) have resisted these portrayals-as if resistance were the only paradigm in which to study the encounter between non-Western worlds and Western powers" (MAKSIDI, 2002 p. 795), indicating that there has been a reluctance to discuss representations of otherness advanced by non-Western regimes as simultaneous strategies of resistance and empowerment, of inclusion and exclusion (ibid., 795). In the same vein, Historian Feroz Ahmad (2014) has suggested that although the Ottoman Empire is recognized as an empire, few writers have discussed Ottoman imperialism, suggesting that like other cases of colonial rule that were challenged by the national movements, the "Ottomans also were forced to decolonize when confronted with emerging nationalism and national movements of their own subjects during and after the French Revolution" (AHMAD, 2014, p.2ff.) derstanding of the Ottoman legacies. If so I shall conclude by highlighting the importance of studies which offer colonial and postcolonial approaches to the analysis of the Ottoman empire (AHMAD, 2014, p.1ff.; DERINGIL, 2003; KÜHN, 2003; MAKDISI, 2002; ELDEM, 2015) ${ }^{15}$, as well as the significance of decolonial knowledge production and epistemic disobedience in challenging dominant ideologies (MIGNOLO, 2011, p. 119, p. 17 ff; 2009 p. 160).

While emphasizing the importance of a non-Orientalised decolonial approach to the study of the Ottoman Empire and as well as the successive nation-states in the Middle East and beyond, I have embraced the emancipatory, critical and deeply humanistic potentials and intellectual legacy of "Orientalism". The purpose of keeping alive its powerful and inspiring critique of imperial and colonial politics, and their discourses of justification across the globe is twofold: first, to expand and further develop the conceptual frames provided by "Orientalism" in order to facilitate decolonial thinking and knowledge production. And relatedly, second, to take a firm position against attempts to use "Orientalism" as a protective shield for the defense of colonial and cruel policies and practices wherever they occur and whoever commits them.

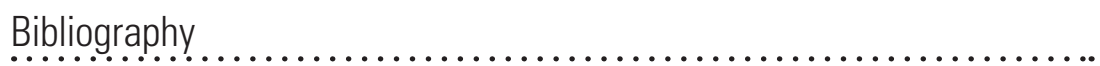

AHMAD, Feroz. The Young Turks and the Ottoman Nationalities Armenians, Greeks, Albanians, Jews, and Arabs, 1908-1918. 1. ed. [S.1.]: University of Utah Press, 2014.

AKÇAM, Taner. From Empire to Republic: Turkish Nationalism and the Armenian Genocide. 1. ed. [S.1.]: Zed Books, 2004.

AKSAKAL, Mustafa. The Ottoman Empire and the First World War. 1. ed. [S.1.]: Cambridge University Press, 2008.

AVIV, Efrat. Millet System in the Ottoman Empire. Oxford Islamic Studies, Oxford, v. 28, n. 1 , p. 1 , nov./2006.

BARKEY, Karen. The Ottomans in Comparative Perspective: Empire of Difference. 1. ed. [S.1.]: Cambridge University Press, 2008.

KARKEY, Karen; GAVRILIS, Gerorge. The Ottoman Millet System: Non-Territorial Autonomy and its Contemporary Legacy. Ethnopolitics, Online, v. 15, n. 1, p. 24-42, dez./2015

BEZWAN, Naif. Türkei und Europa. The Staatsdoktrin der türkischen Republik, ihre Aufnahme in die EU und die kurdishe National Frage, Nomos Verlag. 2008

BLOXHAM, David. The Great Game of Genocide: Imperialism, Nationalism, and the Destruction of the Ottoman Armenians. 1. ed. [S.1.]: Oxford University Press., 2005.

BLOXHAM, David; GERWARTH, Robert. Introduction, in Political Violence in Twentieth-Century Europe. 1. ed. [S.1.]: Oxford: University Press, 2011.

BLOXHAM, David; MOSES, Dirk. Genocide and ethnic cleansing, in Political Violence in Twentieth-Century Europe. 1. ed. [S.1.]: Oxford: University Press, 2011.

BRAUDE, Bemjamin, B. Foundation Myths of the Millet System. In: BRAUD, Benjamin (ed.); LEWIS, Bernard (ed). Christians and Jews in the Ottoman Empire: the functioning of a plural society, Vol.1. New York: Publisher Holmes \& Meier, 1982.

BRAUDE. Christians and Jews in the Ottoman Empire: The Abridged Edition with a New Introduction. 1. ed. [S.1.]: Lynne Rienner Publishers, 2014

BROWN, Carl L. The International Politics and the Middle East, Old Rules, Dangerous Game. 1. ed. [S.1.]: Princeton University Press, 1984

CONNOR, Walker. Ethnonationalism: The Quest for Understanding. 2. ed. Princeton: Princeton University Press, 1994.

Daskalov, DASKALOW, Roumen; VEZENKOV, Alexander The Ottoman Legacy in the Balkans. In: DASKALOV, Roumen (ed.); VEZENKOV, Alexander (ed.). Entangled Histories of the Balkans - Volume Three, Shared Pasts, Disputed Legacies. Leiden: Brill, 2005, pp. 1-9. 
DERINGIL, Selim. "They live in a state of nomadism and savagery": the late Ottoman Empire and the post-colonial debate. Comparative Studies in Society and History, Cambridge, v. 45, n. 2, p. 311-342, may/2003.

ELDEM, Ethem. The Ottoman Empire and Orientalism: An Awkward Relationship. After Orientalism: Critical Perspectives on Western Agency and Eastern Re-appropriations. Brill, Leiden Studies in Islam and Society, Volume 2, 2015 pp. 89-102,

EMRENCE, Cem. Imperial paths, big comparisons: the late Ottoman Empire. Journal of Global History, Cambridge, v. 3, n. 1, p. 289-311, Nov./2008.

EMRENCE, Cem. Remapping The Ottoman Middle East.: Modernity, Imperial Bureaucracy, and the Islamic State. 1. ed. London: I.B. Tauris, 2011.

FROMKIN, David. A Peace to End All Peace: The Fall of the Ottoman Empire and the Creation of the Modern Middle East. 1. ed., New York: An OWL Book, 2001.

GALVÁN-ÁLVAREZ, Enrique. Epistemic Violence and Retaliation: The Issue of Knowledges in "Mother India". Atlantis, Spain, v. 32, n. 2, p. 11-26, dez./2010.

GINGERAS, Ryan. Fall of the Sultanate: The Great War and the End of the Ottoman Empire, 1908-1922. 1. ed. [S.1.]: Oxford University Press, 2016.

GINGERAS, Ryan. Sorrowful Shores.: Violence, Ethnicity, and the End of the Ottoman Empire, 1912-1923. 1. ed. [S.1.]: Oxford University Press, 2009.

GÖÇEK., Fatma M. Reading Genocide, Turkish Historiography on 1915. In: SUNY, Ronald Grigor et al. (ed.). A Question of Genocide: Armenians and Turks at the End of the Ottoman Empire. Oxford University Press, 2011, pp. 42-54.

GREWE, Wilhelm G. The Epochs of International Law. 1. ed., Berlin and New York: Walter de Gruyter, 2000.

HANIOGLU, Sükrü. A Brief History of the Late Ottoman Empire. 1. ed. [S.1.]: Princeton University Press, 2008.

KASABA, Resat. Do States Always Favor Stasis? The Changing Status of Tribes in the Ottoman Empire. In: MIGDAL, Joel S. (ed.). Boundaries and Belonging States and Societies in the Struggle to Shape Identities and Local Practices. Cambridge: Cambridge University Press, 2004, pp. 29-49

KÜHN, Thomas. An Imperial Borderland as colony: knowledge production and the elaboration of difference in Ottoman Yemen, 1872-1914. MIT Electronic Journal of Middle East Studies, Cambridge, v. 3, n. 1, p. 5-17, abr./2003.

LEVENE, Mark. Genocide in the Age of the Nation State. 1. ed. LONDON: I.B. Tauris, 2005.

LEVENE, Mark. The Crisis of Genocide: Annihilation: The European Rimlands 1939-1953. 1. ed. Oxford: Oxford: University Press, 2013.

LEVENE, Mark. The Crisis of Genocide: The European Rimlands 1912-1938. 1. ed. Oxford: OUP Oxford, 2013.

LORY, Bernard. The Ottoman Legacy in the Balkans. In: DASKALOV, Roumen (ed.); VEZENKOV, Alexander (ed.). Entangled Histories of the Balkans, Volume 3: Shared Pasts, Disputed Legacies. Leiden: Brill, 2015, pp. 355-405.

MAKDISI, Ussama. Ottoman Orientalism. The American Historical Review, Oxford, v. 107, n. 3, p. 768-796, jun./2001.

MANN, Michael. The sources of social power: Volume 3, Global empires and revolution, 18901945. 1. ed. Cambridge: Cambridge University Press, 2012.

MANN, Michael. Infrastructural power revisited. Studies in Comparative International Development, Los Angeles, v. 43, n. 1, p. 355-365, dez./2008.

MANN, Michael. The sources of social power: VOLUME 2, The rise of classes and nation-states, 1760-1914. 1. ed. Cambridge: Cambridge University Press, 2012.

MASTERS, Bruce. Christians and Jews in the Ottoman Arab World: The Roots of Sectarianism. 1. ed. Cambridge: Cambridge University Press, 2001.

MELSON, R. Revolution and Genocide: On the Origins of the Armenian Genocide and the Holocaust. 1. ed. Chicago: Chicago University Press, 1992.

MIGNOLO, Walter. Epistemic Disobedience, Independent Thought and Decolonial Freedom. Theory, Culture \& Society, London, v. 26, n. 7, p. 159-181, fev./2010.

MIGNOLO, Walter. The Darker Side of Western Modernity, Global Futures, Decolonial Options. 1. ed. Durham \& London: Duke University Press, 2011. 
MIKHAIL, Alan; PHILLIOU, Christine. The Ottoman Empire and the Imperial Turn. Comparative Studies in Society and History, Cambridge, v. 54, n. 4, p. 721-745, out. /2012.

MYLONAS, Harris. The Politics of Nation-building: Making Conationals, Refugees, and Minorities. 1. ed. Cambridge: Cambridge University Press, 2012

ÖKTEM, Emre. Turkey: Successor or Continuing State of the Ottoman Empire. Leiden Journal of International Law, Leiden, v. 24, n. 1, p. 561-583, ago./2012.

QUER, Giovanni M. De-territorializing Minority Rights in Europe: A Look Eastward. Journal of Ethnopolitics and Minority Issues in Europe, Flensburg, v. 12, n. 1, p. 76-98, jul./2013.

REYNOLDS, Michael A. Shattering Empires: The Clash and Collapse of the Ottoman and Russian Empires, 1908-1918. 1. ed. Cambridge: Cambridge University Press, 2011.

SAID, Edward. Orientalism. 1. ed. London: Penguin Books, 2004.

SHARKEY. Heather J. A History of Muslims, Christians, and Jews in the Middle East. 1. ed. Cambridge: Cambridge University Press, 2017.

SKOCPOL, Theda. Bringing the State Back In. In: EVANS, Peter (ed.); RUESCHEMEYER, Dietrich (ed.); SKOCPOL, Theda (ed.). Bringing the State Back In. Cambridge: Cambridge, University Press, 1985, 3-43.

SOHRABI, Nader. Reluctant Nationalists, Imperial Nation-State, and Neo-Ottomanism: Turks, Albanians, and the Antinomies of the End of Empire. Social Science History, Cambridge, v. 42, n. 4, p. 835-870, mar. /2018.

TAŞ, Latif. The Myth of the Ottoman Millet System: Its Treatment of Kurds and a Discussion of Territorial and Non-Territorial Autonomy. International Journal on Minority and Group Rights, Leiden, v. 21, n. 1, p. 497-526, out. /2014.

TILLY, Charles. After Empire: Multiethnic Societies and Nation-Building. In: BARKEY, Karen (ed.); von HAGEN, Mark (ed.). The Soviet Union and the Russian, Ottoman, and Habsburg Empires. Westview Press, (1997) p. 1-11.

TILLY, Charles. Big Structures, Large Processes, Huge Comparisons. 1. ed. New York: Russell Sage Foundation, 1989

TODOROVA, Maria. Imagining the Balkans: Updated Edition. 1. ed. Oxford: Oxford University Press, 2009.

URSINUS, Michael Zur Diskussion um 'millet' im Osmanischen Reich, in Südost-Forschungen 48, 195-207. 1989.

WHITE, David. State capacity and regime resilience in Putin's Russia. International Political Science Review, Paris, v. 39, n. 1, p. 130-146, dez./2017. 